\title{
A Multimodal Approach to the Anthropocene
}

\author{
Jason M. Kelly and Fiona P. McDonald
}

The Anthropocene is an urgent topic receiving critical engagement across academic disciplines. A concept popularized in the 2000s by Nobel Prize-winning chemist Paul Crutzen and Eugene Stoermer, the Anthropocene refers to the notion that humans have become a global geological force, transforming a multitude of bio-geo-physical environmental systems (Crutzen and Stoermer 2000). The Anthropocene Working Group of the Subcommission on Quaternary Stratigraphy proposed in August 2016 that the International Commission on Stratigraphy name the Anthropocene as a new geological epoch.

The Anthropocene is both a concept and a lived reality. As the Anthropocene is unfolding daily, we find ourselves as social science and humanities researchers engaging with the concept and attempting to contend with the consequences of anthropogenic actions on local and global environmental, social, political, and economic systems. Despite an urgency for interdisciplinary work to respond to the Anthropocene, much research remains bound to disciplinary conventions (Brondízio et al. 2016). In our efforts to respond to the need for more collective and interdisciplinary applied research, in May 2017 we brought together practitioners from across the disciplines to explore what the Anthropocene means to anthropology (and vice versa) by holding a workshop in Indianapolis entitled "Anthropology of the Anthropocene: Structures, Theories, Practices" (AoA) (www.anthropologyoftheanthropocene.org) $)^{\mathrm{i}}$

The workshop was part of the larger Rivers of the Anthropocene project (https://rivers.iupui.edu/cms/) and brought together leading thinkers in cultural, visual, and environmental anthropology; history; public history; sociology; geography; literary studies; museum studies; and philanthropy who have been tackling the sociocultural complexities and experiences of the Anthropocene in recent years. Their geographical expertise spanned six continents. The goal of the workshop was to work collaboratively to address important interdisciplinary and transdisciplinary topics. There were four specific questions that framed the meeting: (1) In what ways are anthropological methods, theories, and practices responsive to the Anthropocene? (2) How do we bridge disciplinary boundaries to advance critical and timely sociocultural research on changing earth systems and the human experience? (3) How are we preparing the next generation of researchers with the right tools, frameworks, and language to design relevant ethnographies? (4) What should a publicly engaged anthropology of the Anthropocene look like? More broadly, these questions encouraged us to think about larger structural issues: What is an anthropology in, of, and for the Anthropocene?

One of the key outputs from the workshop was An Anthropocene Primer, Version 1.0 (http://anthropoceneprimer.org), which we published digitally on October 23, 2017. ${ }^{\mathrm{ii}} \mathrm{An}$ Anthropocene Primer is a born-digital, open-access, participatory online portal created by all of the workshop participants. The primer takes a multimodal approach to the Anthropocene,

This is the author's manuscript of the work published in final edited form as:

Kelly, J. M., \& McDonald, F. P. (2018). A Multimodal Approach to the Anthropocene. American Anthropologist, 120(3), 583-595. https://doi.org/10.1111/aman.13114 
providing a diverse community of users with an entry point into some of the big concepts and debates that dominate interdisciplinary discussions about the Anthropocene. It provides a pedagogical framework to guide individual, collaborative, interactive, and open learning in both formal and informal learning environments. As a living document, it continues to grow through the addition of new content (e.g., learning modules, podcasts, interviews, blog posts), but it also grows through the contributions of the user community in the form of interactive marginalia (discussed later in this article). As such, the primer aligns with the principles of multimodality articulated by Samuel Collins, Matthew Durington, and Harjant Gill (2017). With its emphasis on interdisciplinarity, pedagogy, collaboration, critique, and public engagement, the primer is our response to the questions that framed the AoA workshop, in particular: How are we preparing the next generation of researchers with the right tools, frameworks, and language to design relevant ethnographies for the Anthropocene?

www.anthropoceneprimer.org.

We are using a somewhat autoethnographic tone in this article as a way to open up a space for self-reflexivity about the digital tools we create in order to spark dialogue with the reader. This essay is part of a growing assemblage of works that the Rivers of the Anthropocene Network is producing. ${ }^{\text {iii }}$ The AoA workshop itself has generated a number of outputs, including: (1) An Anthropocene Primer (Kelly and McDonald 2017); (2) "How to Do Open Peer Review in the Anthropocene" for Anthropology News (McDonald and Kelly, forthcoming); (3) a website (anthropologyoftheanthropocene.org); (4) this essay; and (5) an open-access collaborative monograph edited by McDonald and Kelly-Scenes from the Anthropocene-which is in preparation. These works are strategically written to address the questions posed by the workshop and to both analyze and respond to existing theories, structures, and practices and their consequences for understanding and responding to the Anthropocene (Figure 1).

Through their design and implementation, these digital and print outputs embody the strengths, weaknesses, and contradictions inherent in multimodal landscapes. Each output responds to disciplinary practices and expectations associated with editorial peer review (for example, this essay), double-blind peer review (for example, the Scenes from the Anthropocene collective volume), and open peer review (the primer). They are shaped by structural limitations, including the economics of the twenty-first-century publication landscape, which determines whether an article is behind a paywall (such as this essay and the Anthropology News article) or open access (the primer, the website, and the collective volume), the extent to which authors might be able to find money to fund open-access works, or what the ethical obligations might be for scholars to share their work. Likewise, these works operate in a landscape in which formal, academic writing is being transformed by new modes of collaborative, participatory, and open writing outside of traditional publishing frameworks. 
Using An Anthropocene Primer as our case study, this essay is organized into three sections. The first section introduces the primer as a tool that bridges disciplinary boundaries to advance critical and timely sociocultural research examining changing earth systems and the human experience. The second section examines the ways that anthropologists might productively engage with the dominant interdisciplinary debates and metanarratives about the Anthropocene and the role that tools such as the primer might play in this. The final section reflects on how the primer is one model of multimodal pedagogy that answers the needs of formal, informal, traditional, and continuing education in relation to serious play. In part, then, An Anthropocene Primer is one form of anthropological educational practice that might be used to prepare the next generation of researchers and partners with frameworks to pursue ethnography in the Anthropocene that is truly applied, interdisciplinary, and multimodal at the outset.

\section{An Anthropocene Primer}

An Anthropocene Primer was initially conceived to provide a document that would introduce scholars and students alike to the complicated, interdisciplinary debates around the Anthropocene. The need for a work of this nature became apparent to us as we were creating the outline for the AoA workshop. We noticed a gap in the literature that would help us frame keywords and boundary concepts associated with the Anthropocene that could act as a baseline from which all of the workshop attendees could start (Dewulf et al. 2007; Mollinga 2010; Williams 1985). We decided to create one ourselves because there was no single source that could provide us with an introduction to the multiple metanarratives of the Anthropocene or that explored the varieties of approaches to and understandings of the Anthropocene.

We recognized the need for a resource of this type for two reasons. First, we are an interdisciplinary team - a historian and an anthropologist — who, while working together nearly every day, often found it necessary to elucidate our different perspectives, frameworks, and methods. Second, the Rivers of the Anthropocene Research Network, which is made up of dozens of scholars from across disciplines, identified the need for recognizing boundary concepts and putting them at the center of our conversations back in 2013. The primer, then, was created in collaboration with a range of authors in order to develop and share insights into how scholars with different disciplinary expertise framed, imagined, and responded to questions and boundary concepts.

We decided to use the AoA workshop - with participants from different fields and areas of expertise - to develop the primer's framework and content. From the beginning, everyone in the workshop wanted it to be an open-access text so that people from around the world had free access (McDonald and Kelly, forthcoming). Likewise, the group decided that it should not be a publication limited to academia. We needed to write something that could be used for community conversations and for educating donors and foundations, or used by individuals pursuing continuing education on the web. While we would have liked the text to be available in multiple languages, we did not have the funds to hire translators at this early stage. That said, we expect to have a Spanish translation available in 2019, prepared by Alejandro Camargo. We would like to add other languages as the primer continues to grow. Hosting the primer online allowed us to make it open access. It also opened up what we could do with media. We could use sound, video, and interactive discussions to examine the range of ideas that are simply 
impossible in a traditional book format. While we made every effort with the resources on the WordPress platform to ensure that images and text are accessible for sensory-impaired readers, additional work is still needed to provide closed-captioning for videos. Because the primer links to external videos and sites, ensuring those platforms are also accessibility compliant is a true challenge.

The primer is divided into several sections. On the landing page (www.anthropoceneprimer.org), we introduce users to the concept of the Anthropocene. We also explain to users the design of the primer and several of its key features. George Marcus provides the foreword to the primer, which is then followed by three short essays: "What is the Anthropocene?," "Taxonomies of Geological Time and the Anthropocene Epoch," and "Concepts." These essays are not meant to be definitive. Rather, we designed them to provide the most basic entry point for absolute beginners - people who may never even have heard of the Anthropocene.

The next section in the primer is the "Syllabus." This is a core element of the primer's content and is where readers get into the meat of the primer. Currently, it is made up of five modules:

1. What is the Anthropocene?

2. Ethics, Justice, and Responsibility

3. Anthropocene Voices

4. Scale

5. Policy

We will add new sections periodically, and the wider user community can propose additions to the editors. As the online tutorial explains, each of these modules has several parts: a summary of the module, keywords, learning outcomes, readings, and activities. We were intent that the primer be useful to both novices and advanced scholars who already work on issues related to the environment. So, we designed each module of the syllabus with three levels. Beginners could start by completing only the items in green. When they were finished with those, they could move on to the intermediate level of the module in blue, and then the advanced level in red. Alternatively, anyone can read across the entire primer at a specific learning level. In this sense, each reader can choose their own path in learning about the Anthropocene (Figure 2).

Each module in the syllabus - whether beginner, intermediate, or advanced - has five parts. First, "Beginners/Intermediate/Advanced Questions" frame the readings and activities. Second, the "Beginners/Intermediate/Advanced Readings" are divided into "Narrative," "Theory," and "Practice." This organization mirrors to some extent the structures, theories, and practices framework that we used in the AoA workshop. We designed each of these categories in a different font to help readers differentiate them in the same way the colors denote expertise levels. "Narratives" focus on the ways that we frame our questions, often through providing case studies or instructional texts. "Theory" readings are more conceptual, and in the more advanced sections, they can be quite challenging. The "Practice" readings examine how people on the ground respond to the module theme. Readings are usually text based, but they can include video or audio. For example, "Module 4: Policy" asks users to watch Ludovico Einaudi's performance of "Elegy for the Arctic" (2016); the VPRO Documentary film "The Anthropocene: The Age of Mankind" (2017); and Ligorano Reese's street interviews for the public art project "Dawn of the 
Anthropocene" (2014). At the end of each reading section, there is an activity that helps users reflect upon and apply what they have learned through the readings. One of the greatest challenges in designing the modules was trying to provide as many key readings/videos as possible while making sure that the large majority of the readings were open access. This meant that several of the readings we would have liked to include in our syllabus were left out of the primer in favor of more accessible texts.

We included a separate "Activities" section in each module that offers users collaborative, active learning exercises with tactics for engaging with the Anthropocene. They encourage users to link the global phenomena of the Anthropocene to their local contexts and personal experiences. These activities flesh out the ideas in the "Readings" section, but they are not dependent on them. The current set of exercises ask people to reflect on deep time in order to question the assumptions that they have about the environment and to explore the history of the anthropogenic landscapes where they live. One of the activities, "Framing the Anthropocene," specifically addresses the problem of framing, boundary concepts, and keywords (Williams 1985). It is a group activity that would be particularly useful for a research team just starting a project together (igire 3 ).

The primer also includes a series of bibliographies about the Anthropocene that cover issues such as capitalism and empire, gender and feminism, new materialism, and ethics. Like the other sections, these are constantly expanding and transforming, and there are bibliographies for beginner, intermediate, and advanced levels. The themed bibliographies are not meant to be definitive or exhaustive but rather are provided for users who have worked through the syllabus and are interested in exploring specific ideas further. They may also be useful for faculty members who want to integrate readings into their syllabi that reflect the current debates about the Anthropocene or for museum professionals and curators looking to do preparatory research for an exhibition.

As the paragraphs above show, An Anthropocene Primer can be used in both linear and nonlinear approaches to multimodal learning. It is open access and exists in multiple media formats. Taken on their own, the sections of the primer provide templates for both formal and informal learning. But we wanted to create a multimodal platform that was also interactive-something that could perhaps help foster dialogue among the user community and act as the tool for open peer review. To do this, we integrated Hypothes.is (https://hypothes.is), a plugin that allows authors to highlight and annotate text as well as have conversations with each other in the marginalia (Figure 4).

This system is useful because it allows individuals to keep private notes. It also allows teachers and their students to have private group discussions that engage with the primer. In the first version of the primer, we have been using Hypothes.is as a tool to facilitate open peer review. It allows users to comment on our text and allows us to engage with them through an open discussion. We discuss this in detail in "How to Do Open Peer Review in the Anthropocene" in Anthropology News (McDonald and Kelly, forthcoming). Insight gained from the open peerreview process will be incorporated in the additional versions of the primer, and anyone who participated in the open peer-review process will be recognized as a contributor to future editions. This model ensures that all labor and expertise is accounted for. In a video on the 
landing page, we demonstrate how to use this interactive functionality of the primer. www.anthropoceneprimer.org/index.php/videotutorials/

In sum, the elements that define An Anthropocene Primer are its multimodality, interactivity, and extensibility. Considering how quickly the literature on the Anthropocene is growing and how significant the concept is becoming to multiple disciplines, these elements are essential. They allow authors and users to respond to this changing landscape and to interact with each other in meaningful and timely conversations. Unlike a paper-based book, the primer allows us to edit, to prune, and to add content. It also allows us to develop new media formats, highlight new works for the user base, and keep pace with emerging trends in digital publishing.

In the next sections of this essay, we turn to explore why this design is significant for anthropology — specifically as it relates to the place of anthropology in, of, and for the Anthropocene.

\section{Anthropocene Debates And Anthropology}

The "Anthropocene" has quickly become an important topic receiving critical engagement across many disciplines. In its most simplistic form, the Anthropocene designates a moment in the planet's history when humans became a geological force, leaving a permanent, measurable mark on the planet (Crutzen and Stoermer 2000; Lewis and Maslin 2015; Ruddiman 2003; Steffen et al. 2011; Zalasiewicz 2015; Zalasiewicz et al. 2015; Zalasiewicz, Williams, Fortey, et al. 2011; Zalasiewicz, Williams, Haywood, et al. 2011; Zylinska 2014). Of course, a scientific concept such as the Anthropocene-which has been quickly absorbed into the discursive fields of the social sciences, humanities, and arts - has much richer connotations and associations. The emergence of the Anthropocene has been tied to a range of ideas about humanity's place on the planet. It speaks to the ways humans have shifted a range of Earth systems: carbon, nitrogen, phosphorous, water, and so on. It encompasses the ways that we imagine political, social, and economic systems (Biermann 2014; Guattari 2014; Purdy 2015). It spurs us to examine our own ethical positions — our notions of justice, responsibility, and equality (Ghosh 2016; Lövbrand et al. 2015; Martinez-Alier 2003; Nixon 2013; Schmidt, Brown, and Orr 2016; Stone 2010; Walker 2009; Zalasiewicz et al. 2008). It challenges us to come to terms with the ways we conceptualize our ways of being: ideas about humanity and humanness, our relationships with each other, and our place in a multispecies world (Bennett 2010; Cohen 2015; Haraway 2007; Kohn 2013; Morton 2017; Tsing 2015).

But to engage with the Anthropocene is to do more than examine a concept. The Anthropocene implies a lived experience. It is about the pasts, presents, and futures of humans as well as fauna, flora, rocks, and waters. Understanding the Anthropocene is not about defining the moment when humanity became a geological force. It is about understanding the history of feedback loops and cascades between biogeophysical processes and sociocultural processes. It is about excavating histories and understanding the ways that resource extraction, slavery, capitalism, imperialism, urbanization, industrialization, and warfare worked together for hundreds of years to reshape the planet (Angus 2016; Bonneuil and Fressoz 2016; Chakrabarty 2009; Jonsson 2012, 2014; Malm 2016; Malm and Hornborg 2014; A. Moore 2015a; J. Moore 2016). It is about 
understanding how these environmental effects are experienced differently across the globe. It is about responding to this context in productive and meaningful ways.

In the social sciences and humanities, many of us have been answering Bruno Latour's (2014) call for anthropologists to recognize the centrality of the discipline in addressing the key problems of the Anthropocene. His work has encouraged us to think about how the notion of the Anthropocene can be used to think through the futures of anthropology. As he and Philippe Descola point out, anthropology is not necessarily a single discipline because all of our subfields continue to merge and emerge (Latour and Descola 2013). As we speed through the twenty-first century, the discipline shifts even more with the continual emerging and merging of subfields beyond the four-field anthropological project.

Anthropologists have been actively documenting the experience of the Anthropocene through their ethnographies since the discipline began (Baer and Singer 2014; Howe and Boyer 2015; A. Moore 2018; Tsing 2015). These ethnographies serve as data points. With them, we have refined our methods, reframed our approaches in more ethical ways, and built an archive of societies' behaviors, values, and beliefs. These ethnographies underscore the observation that there is no homogeneous Anthropos - a generic human force with a single agential quality - to blame for the Anthropocene. Moreover, the move to self-reflexivity has revealed our positionality: scholarly practitioners living out the Anthropocene's lived realities while simultaneously studying its dynamic nature and conceptualizing its meanings beyond just a documentation of the catastrophic. This approach is distinct from the vast swathe of scholarship on the Anthropocene in which humans are often reduced to a single variable and studied from a realm of ostensible objectivity and distance. We believe that anthropology has much to offer in how our knowledge of the Anthropocene is constructed and embodied through scientific practices, how it is experienced differentially across the globe, and how we respond to it culturally, politically, economically, and so on. We believe that anthropology is poised to lead new approaches that address some fundamental problems in research associated with the Anthropocene.

While anthropologists in the nineteenth and early twentieth centuries distanced themselves from the environmental determinism of their Enlightenment forbearers, their work - explicitly or not-was nevertheless often concerned with the relationship between people and their environments (Barnes and Dove 2015). As Michael Dove notes, studies of subsistence practices, for example, were effectively studies of the interactions between humans and their environments (Dove 2013, 2). By the 1950s and 1960s, the work of Julian Steward, Harold Conklin, and Richard Netting set a template for contemporary environmental anthropology (Brondízio 2016; Conklin 1955; Crate 2011, 177; Dove 2013, 2; Netting 1968; Steward 1955). This interest in the environment during the middle decades of the twentieth century mirrored that in other social sciences and humanities fields, and it was during these decades that environmental sociology and environmental history also emerged. This concern with the environment had numerous causes. On the one hand, the post-World War II period was an age of massive state investment in research on weapons of mass destruction - nuclear, biological, and otherwise. This work focused scientists, social scientists, and critics alike on the potential for humans to cause irreversible environmental catastrophes (Hamblin 2013). These were also the decades when the effects of industrialization, urbanization, commercial agriculture, and population became an increasing concern for governments, most notably demonstrated in Rachel Carson's ([1962] 2002) Silent 
Spring and the Club of Rome's Limits of Growth report (Meadows et al. 1972). By the 1990s, the Environmental Section of the AAA was formed.

In many ways, then, anthropology as a discipline was primed for engaging with the concept of the Anthropocene when the concept gained traction in the first decade of the twenty-first century. This was doubly the case as the discipline was also beginning to tack toward the global, increasingly connecting micro studies and locally based ethnographies with broader systemic shifts tied to processes associated with "globalization." By the 2010 s, climate change was a key concern of environmental anthropologists (Brondízio et al. 2016; Crate 2011), but it was the introduction of the Anthropocene into the lexicon that began to capture the imagination of a broader range of researchers (Howe 2015; Howe and Pandian 2016; A. Moore 2015a, 2015b).

What the Anthropocene means for the futures of anthropology remains to be seen, but there appear to be five interrelated areas where anthropologist are particularly active: multispecies ethnography, interdisciplinary engagement, understanding narratives about the Anthropocene, the documentation and narration of environmental change, and connecting local experience to global environmental processes, especially relating to migration. Multispecies ethnographies have been particularly effective at demonstrating how Western-centric notions of the Anthropos are limited conceptual frameworks for understanding the experience of the Anthropocene. They have challenged simplistic dualisms (e.g., nature/culture), shown their destructive tendencies, and suggested a number of philosophical and political responses (Bennett 2010; Kirksey 2014; Kirksey and Helmreich 2010; Latour 2004, 2017). The concept is inherently interdisciplinary, so it is not surprising that a number of projects have emphasized ways to foster collaborations between scientists, social scientists, humanists, and policymakers (e.g., Future Earth and IHOPE). One of the greatest challenges in bridging disciplinary divides is sustaining projects in which one mode of disciplinary thinking and practice does not subsume the other (Costanza et al. 2012; Lorimer 2012; Toivanen et al. 2017). Closely related to interdisciplinarity is an attempt to understand the metanarratives and discourses of the Anthropocene, an approach that has its intellectual roots in science and technology studies (Foucault 1994, 2010; Latour 1988, 2005; Latour and Woolgar 1986; Shapin 2010; Shapin and Schaffer 1989). Work in this vein is often a critique of the Anthropocene concept and the scientific and political assumptions that underlie it (Bonneuil and Fressoz 2016; Malm and Hornborg 2014; J. Moore 2015). The documentation and narration of the Anthropocene encompasses a profound number of well-researched case studies on the environment (Campbell 2005; Ghosh 2016; Howe and Boyer 2015; Ingold 2000; Wagner 2013). Ethnographies are critical to documenting the experience of rising sea levels, global warming, dying coral reefs, deforestation, and social injustices on Indigenous lands. Connecting these ethnographies to global narratives is a key challenge for our understanding of the Anthropocene. As Susan Crate $(2011,185)$ suggests, one way to do this is through what she calls "climate ethnography," or "the development of a new multisided, critical collaborative ethnography that integrates a refinement of how we account for human perceptions, understandings, and responses by both modifying resilience/adaptation frames and further developing cultural models." A complementary approach might necessitate interdisciplinary projects that integrate sophisticated modeling to examine coupled socioecological systems (Brondízio and Moran 2013; Brondízio et al. 2016). 
An anthropology in, of, and for the Anthropocene is complex because we are all living through it. The ways in which we can engage with communities, colleagues, and students might rest on the idea of embracing more participatory research methods and theoretical analysis that is multimodal from the outset.

\title{
Serious Play and the Pedagogy of An Anthropocene Primer
}

As a mode for productive dialogue, An Anthropocene Primer is a platform that opens up conversations about the Anthropocene as both concept and lived experience. It removes linearity, embraces the contradictory attributes of the Anthropocene concept, and recognizes the multiplicity of lived realities inherent to Anthropocene environmental change. In this sense, $A n$ Anthropocene Primer is a technology for participating in a twenty-first-century form of "serious play" with the Anthropocene-for academic and nonacademic learners alike. We follow Anna Tsing who suggests that serious play with the Anthropocene has the potential to open up new ways of thinking, new cross-disciplinary conversations, and new modes of critique (Haraway et al. 2016). As Tsing suggests, the Anthropocene concept is "still so multiple and inchoate that it maintains potential" (Haraway et al. 2016, 541). This potential, she argues, has the possibility of bringing together interdisciplinary collaborations as well as spurring critical thinking across disciplinary boundaries (Haraway et al. 2016, 541). We believe that open-access multimodal tools that foster serious play, such as An Anthropocene Primer, can be a tangible and potent response to the call for interdisciplinary collaboration in Anthropocene research by Brondízio et al. (2016) in "Re-Conceptualizing the Anthropocene: A Call for Collaboration" (see also Dewulf et al. 2007). To understand this, it is worthwhile exploring what we mean by serious play.

The concept of serious play has become increasingly popular in recent years, especially in the fields of organizational management and education. In these realms, serious play is usually focused on classroom gamification, digital environments, and team-building exercises to accomplish specific goals (Beavis, Dezuanni, and O'Mara 2017; Beech et al. 2004; Bogost 2010; Kristiansen and Rasmussen 2014; Statler, Heracleous, and Jacobs 2011; Statler, Roos, and Victor 2009). What unites these literatures is an emphasis on serious play with directed outcomes.

But, there is a deeper history of serious play that can be traced to the classical world. In his Ars Poetica, Horace writes:

\author{
Aut prodesse volunt aut delectare poetae \\ aut simul et jucunda et idonea dicere vitae \\ Omne tulit punctum qui miscuit utile dulci \\ lectorem delectando pariterque monendo
}

Poets aim either to benefit, or to amuse, or to utter words at once both pleasing and helpful to life. 
He has won every vote who has blended profit and pleasure, at once delighting and instructing the reader. (Horace $\underline{1929}, 333-34,478-79)$

This principle of combining delight and instruction was key to the Renaissance practice of serio ludere - serious play. Humanists, inspired by ancient writers such as Apuleius and Lucian, developed serio ludere (sometimes seria ludo) as a rhetorical mode full of jokes and stories performed in order to discover deeper truths (Collins 2002, 31-37; Findlen 1998). Among the form's early modern practitioners were Ariosto, Erasmus, More, Rabelais, and Swift (Kennedy and Norton 1989, 199-200). In summarizing the work of Nicolaus Cusanus, Edgar Wind offered a classic definition of serio ludere that helps elucidate the concept: "These serious games (serio ludere) consisted in finding within common experience an unusual object endowed with the kind of contradictory attributes which are difficult to imagine united in the deity" (Wind 1968, 222). Wind's definition has echoes in André F. Droogers's notion of "methodological ludism" in which "the ludic is the capacity to deal simultaneously and subjunctively with two or more ways of classifying reality" (Droogers 1996, 53; 1999; Knibbe and Droogers 2011). To craft his definition of "methodological ludism," Droogers relied on Victor Turner, who wrote that "I sometimes talk about the liminal phase being dominantly in the 'subjunctive mood' of culture, the mood of maybe, might-be, as-if, hypothesis, fantasy, conjecture, desire, depending on which of the trinity, cognition, affect, and conation (thought, feeling, or intention) is situationally dominant" (Turner 1990, 11-12).

The Anthropocene is, to use the language of Edgar Wind, "an unusual object endowed with the kind of contradictory attributes which are difficult to imagine united" $(1968,222)$. As such, serious play as an approach to the Anthropocene has the potential both to elucidate and to open up the concept for contemporary scholarship and practice. We think four traits of serious play are particularly apt for engaging with the Anthropocene - and for understanding the principles underlying An Anthropocene Primer. First, serious play is not simply a form of amusement; there are stakes to serious play. These might be socioeconomic, as in the case of "deep play" described by Geertz (1972) and Bentham $(1864,131)$, or they might be environmental, as they are with the Anthropocene. The stakes are never purely intellectual. Serious play with theories about the Anthropocene has consequences for politics, policies, pedagogies, and more. Second, serious play with the Anthropocene is a nonlinear practice. The goal is not to arrive at a universal or universalizable definition or set of responses. Rather, serious play with the Anthropocene concept is experimental, contradictory, and generative. It focuses on the liminal "might-be, asifs" suggested by Victor Turner $(1990,11)$. Reveling in ambiguity, it has the potential to shed light on and provoke new responses to our ways of thinking and doing. Third, serious play is an intersubjective, sociable experience. It requires collaboration both across the disciplines and across structural boundaries, whether disciplinary, institutional, or sociocultural. Finally, serious play is a method for generating critique. It is an iterative process of development meant to challenge and reshape our theoretical frameworks, our disciplinary structures, and our methods and practices.

Through serious play - both in content and form-An Anthropocene Primer participates in overlapping and complementary scholarly practices central to the futures of anthropology. Perhaps most significantly, it fulfills a pedagogical role, blending formal, informal, traditional, 
and continuing learning. The multimodal structure emphasizes and embodies experiment, ambiguity, intersubjectivity, and critique. The primer provides a space for collaboration in which all participants are learners and have the capacity to create new interpretations and build together. Doing so situates the serious play of An Anthropocene Primer within the realm of critical pedagogy (Freire 2000; Giroux 2011; hooks 1994), answering a need for a pedagogy of the Anthropocene that reimagines what we study, how we analyze it, and how we understand the institutions in which we operate (Rousell 2015). When considering potential futures for anthropology, we can use the primer to provide a pedagogical model that serves the parallel missions of anthropological training and applied practice. An Anthropocene Primer offers multiple paths for knowing while providing a model for the ways that critical pedagogy in, of, and for the Anthropocene might be practiced from multiple cultural perspectives.

One of the most pressing concerns of an anthropology of, in, and for the Anthropocene is our responsibility to train the next generation of scholars (Stoller 2018). Not only will this generation be forced to grapple with the conceptual legacies of the Anthropocene-in particular, the embodiment of these legacies in theoretical and methodological models - but this generation is living in an age of dramatic environmental transformation. Their worlds and the worlds of the communities with which they work will force them to respond to emerging conditions, including environmental disasters, massive migrations, and resource shortages. Because of this, we think that it is essential that the Anthropocene be placed centrally in anthropological education. In order to do this, educators and students alike must be willing to integrate and engage with the rapidly expanding set of knowledges around the Anthropocene. The primer provides the tools and a model for doing this through the open peer-review functionality. But, its development points to some of the structural challenges inherent to shifting current practices.

Our vision of an anthropology in, of, and for the Anthropocene requires new experiments, including multimodal tools that embody interdisciplinary and ethical practices for an engaged anthropology. From an ethical position, we think that at the very minimum projects such as the primer need to be freely available to the widest audience possible through open access. ${ }^{\text {iv }}$ As basic as this position might seem, open access exists within the economics of capitalist systems; providing information is not free, nor is retrieving it. This limitation maps itself onto a second principle we think is important: the democratization of knowledge access (McDonald and Kelly, forthcoming). When building the primer, we cocreated it with a team of people from six continents whose experience and expertise ranged across multiple sectors, both within and beyond academia as well as from various cultural lenses. What resulted was an interdisciplinary, participatory tool that can serve multiple purposes and multiple audiences. New elements can be codesigned, built, and extended by students, anthropologists, and the communities with which we work - all the while facilitating dynamic interactions between them. It is, therefore, a tool that not only provides a unique learning experience but also models how a digital platform might break down some of the barriers to participation in the realm of knowledge production (McDonald and Kelly, forthcoming). Supporting these collaborations, however, required significant institutional financial help - to assemble the original team of cocreators as well as support the editors as they continue to develop the primer. What we have also found is that despite the openness of the primer, participation requires constant coordination, ranging from marketing to organizing group reads. In other words, without constant maintenance, research, and facilitation, these types of projects do not have a life of their own. 
Our commitment to knowledge in a pedagogical context brought us to the principle of extensibility as a key feature of a multimodal anthropology in, of, and for the Anthropocene. In order to achieve this, we needed a dynamic system of publishing that allows for new features and welcomes participation by a broad community of participants. This requires two things. First, as we have already indicated, it requires editors that have made a commitment to maintaining and extending the platform. Second, it requires a new mode for thinking through the process of publication. In traditional academic publication, the goal is to complete a finished "work" with a set of coherent ideas that build to a single argument. These are recognized by the community of scholars through the imprimatur of a press that has put it through peer review and a series of editorial processes. At the end of this process, the text is necessarily fixed. Any changes require authors to go through this process again in order to create a new edition, with huge investments of institutional resources. Because of this, new editions are the exception, not necessarily the norm. This mode of operation has slipped into our processes in the digital world as well. The vast majority of digital texts follow this same path - especially those that are produced through publishers. In a realm that has the potential to be dynamic, ever changing, and interactive, digital texts, like their analog predecessors, become fixed - not because of the limits of technology but because of the procedures inherent to the institutionalization of knowledge. Making $A n$ Anthropocene Primer extensible meant that the work would never be fixed - that modules, readings, and themes could transform to reflect the changing needs of users and, therefore, there would be multiple open-access versions. The consequences of this are twofold. First, this approach puts limits on the modes in which the primer can exist; effectively, its core functionalities require online publication - even if a portion of the text is developed for an analog format. Second, in a world in which academic value is measured by the imprimatur of a wellrespected press, authors must either find a publisher willing to experiment in new formats that are unlikely to recoup the costs of publication (Version 1.0 of An Anthropocene Primer is under review with Indiana University Press), or they need to work in a university system willing to evaluate the scholarly value of digital objects without resort to traditional forms of peer review.

The challenge posed to anthropology in responding to the Anthropocene is, in part, a pedagogical one, an institutional one, and a publishing one. It is also fundamentally an ethical one about access and participation. Using the multimodal framework of the primer creates a realm for serious play that has great value in anthropological training in, of, and for the Anthropocene. It helps inform as well as model practices for interdisciplinary engagement, dialogue, and multimodality between numerous users globally, locally, and interculturally. Shifting practices, however, also necessitate shifting structures - the institutions with which we work, the scholarly practices and expectations with which we have become accustomed, and the financing system in which we operate.

\section{Conclusion}

A multimodal approach to the Anthropocene-one that allows us to interact, engage in open dialogue, and offer formal and informal pedagogical tools for diverse communities through serious play - is much needed. Using An Anthropocene Primer as our case study points to how the key definitions and debates of the Anthropocene span disciplines, communities, and thematic foci. An anthropology in, of, and for the Anthropocene requires us to change our pedagogical 
modes and tools to make them more collaborative, open, participatory, and responsive to both emerging scholarship and the contexts in which learning takes place.

It is safe to say that we need new theories, structures, and practices for the Anthropocene. One important way to achieve this is to create multimodal ways to engage in interdisciplinary work. We do not necessarily know where anthropology needs to go in the next decade as disciplines merge and subfields emerge, but we do believe that future approaches for applied work will need to respond to rapidly changing learning contexts and environmental systems that began years ago.

\footnotetext{
${ }^{i}$ this workshop was generously funded by the Wenner-Gren Foundation and the Indiana University New Frontiers Award for Arts and Humanities. www.anthropologyoftheanthropocene.org

ii Editors: Jason M. Kelly (IUPUI, USA), Fiona P. McDonald(University of British Columbia, Canada); Authors: Jason M. Kelly (IUPUI, USA), Fiona P. McDonald (University of British Columbia, Canada), Alejandro Camargo (University of Montréal, Canada), Amelia Moore (University of Rhode Island, USA), Mark Kesling (The daVinci Pursuit, USA), Ananya Ghoshal (Forum on Contemporary Theory, India), George Marcus (University ofCalifornia, Irvine, USA), Paul Stoller (West Chester University, USA), Dominic Boyer (Rice University, USA), Serenella Iovino (University of Turin, Italy), Rebecca Ballestra (Artist, Monaco/Italy), Eduardo S. Brondízio (IU, Bloomington, USA), Jim Enote (A:shiwiw A:wan Museum and Heritage Center, Zuni, USA), Ignatius Gutsa (University of Zimbabwe, Zimbabwe), Cymene Howe (Rice University, USA), Sue Jackson (Griffith University, Australia), Phil Scarpino (IUPUI, USA).

iii See, for example, Kelly et al. (2017) Rivers of the Anthropocene (https://www.luminosoa.org/site/books/10.1525/luminos.43/) and Kelly (2015) Fjord/Glacier/River (www.jasonmkelly.com/fjordglacierriver-allan).
}

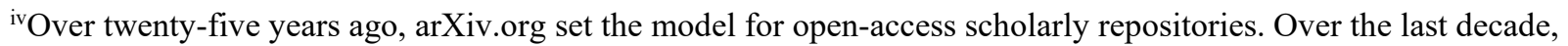
the number of open-access journals has expanded rapidly, especially in the sciences. In our field, Cultural Anthropology has set a new benchmark for open access as well. Research universities across the world have established dataset and preprint journal repositories. They even host open-access journals on platforms such as Open Journal Systems (OJS). More recently, both nonprofit and for-profit scholarly presses have established open-access monograph series, such as University of California Press's Luminos and University of Michigan Press's digitalculturebooks. The reasons for the widespread interest in open access is complex, but it would be fair to say that (at least for those in the nonprofit sector) stakeholders would like to see scholarly research available to everybody. Of course, the ideal of open knowledge is far from a reality. Scholars are entangled in an institutional nexus of universities, professional organizations, and publishers driven by their own logics, professional norms, and economic incentives. These bodies delimit our choices. In doing so, they are shaping what open-access practices might look like. In many cases, open-access digital publishing to date simply mirrors analog processes and outputs. In reflecting on this, it is helpful to distinguish open access - that is, the capacity for the free exchange of knowledge in the digital environment-from the infrastructures, principles, and practices that allow this free exchange. These infrastructures, principles, and practices are contested domains, constantly in flux. They determine ownership, access, and use of knowledge in the digital domain. The recent FCC ruling on "net neutrality" is only the most recent demonstration of conflict in this arena. It is a poignant example of the stakes involved and the ways in which a public resource - in this case, the Internet—might become privatized. 


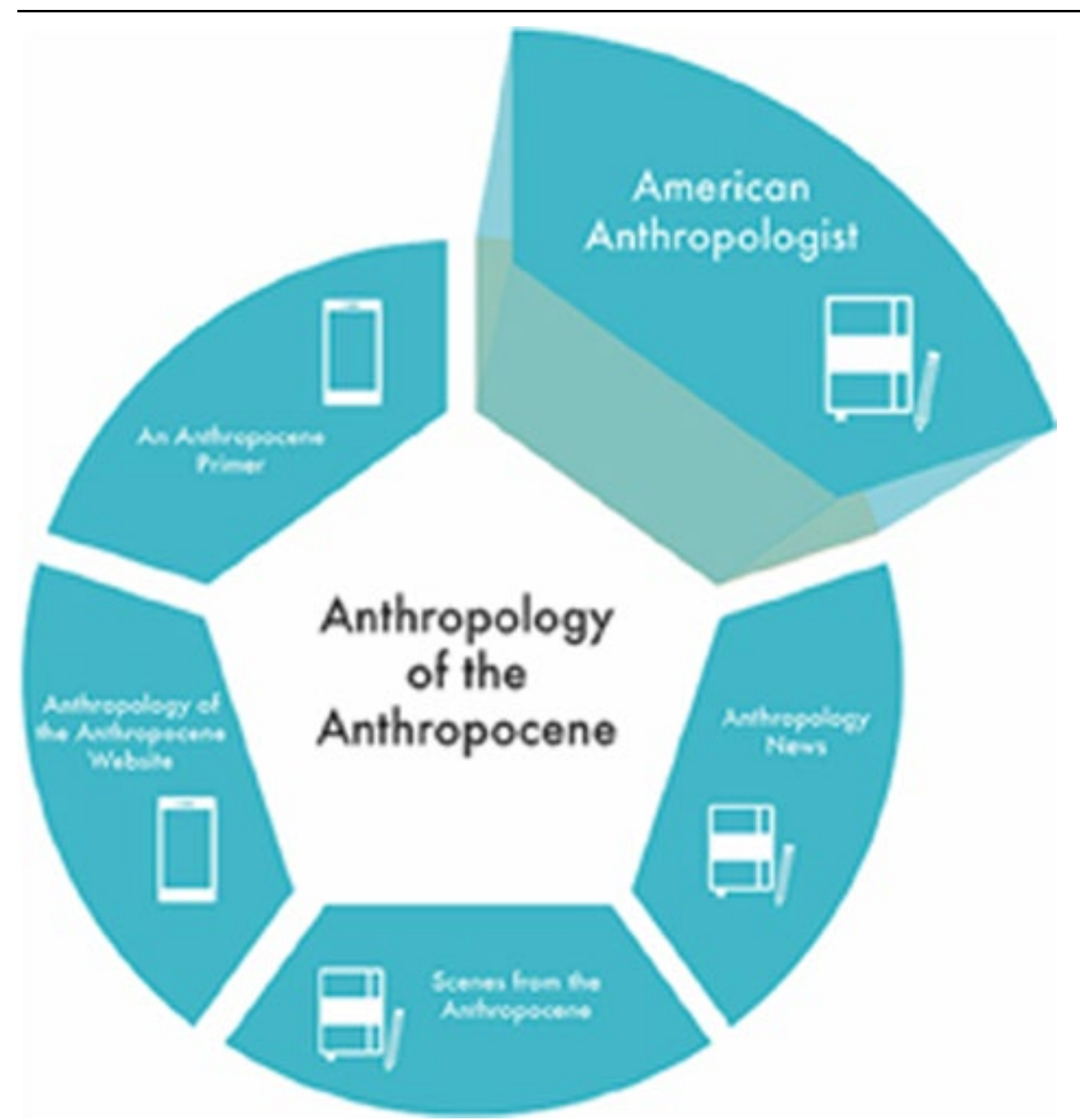

Figure One. Anthropology of the Anthropocene digital and textual outputs. (Courtesy of authors) 


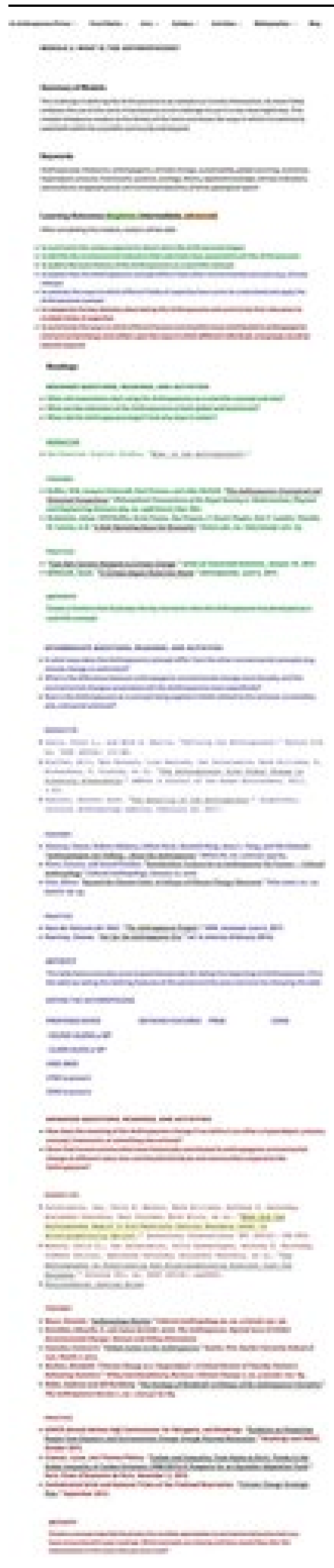

Figure 2. Module 1: What is the Anthropocene? (Courtesy of authors) 


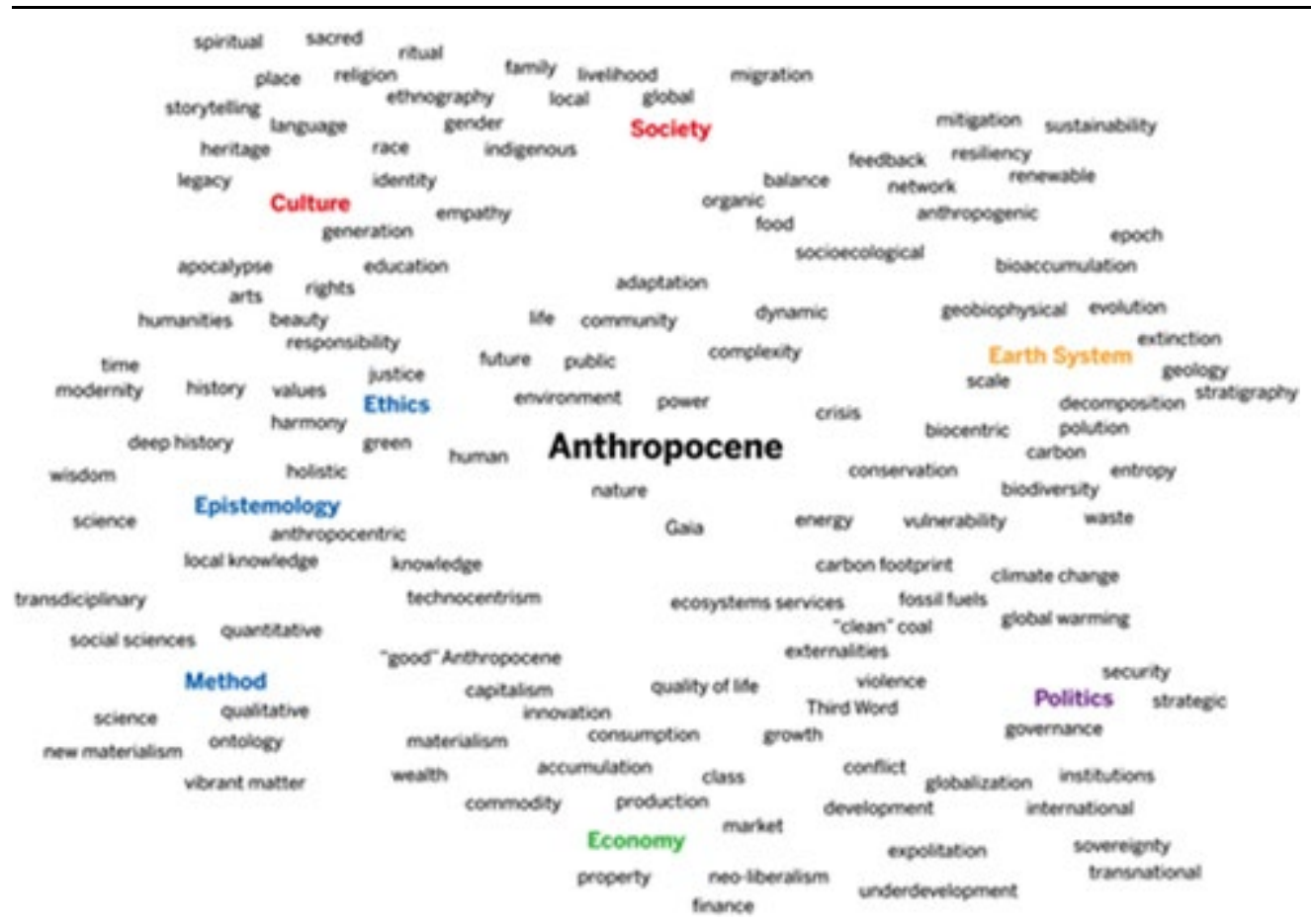

Figure 3. Framing the Anthropocene. (Courtesy of authors)

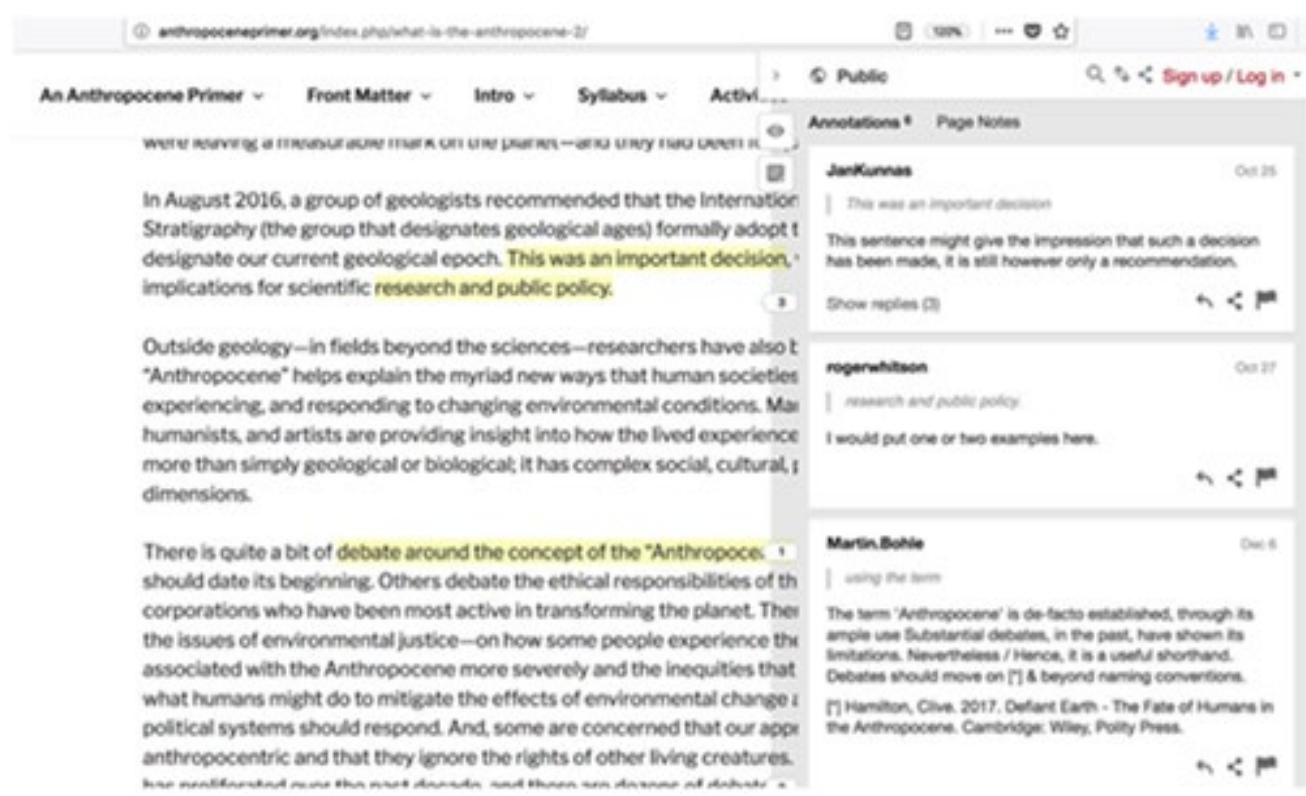

Figure 4. Hypothes.is in use on An Anthropocene Primer. (Courtesy of authors) 


\section{$\underline{\text { References Cited }}$}

Angus, Ian. 2016. Facing the Anthropocene: Fossil Capitalism and the Crisis of the Earth System. Reprint edition. New York: Monthly Review Press.

Baer, Hans, and Merrill Singer. 2014. The Anthropology of Climate Change: An Integrated Critical Perspective. London: Routledge.

Jessica Barnes, and Michael R. Dove, eds. 2015. Climate Cultures: Anthropological Perspectives on Climate Change. New Haven, CT: Yale University Press.

Barthes, Roland. 1975. S/Z: An Essay. Translated by Richard Miller. New York: Hill and Wang.

Catherine Beavis, Michael Dezuanni, and Joanne O'Mara, eds. 2017. Serious Play: Literacy, Learning and Digital Games. New York: Routledge.

Beech, Nic, Harry Burns, Linda de Caestecker, Robert MacIntosh, and Donald MacLean. 2004. "Paradox as Invitation to Act in Problematic Change Situations.” Human Relations 57 (10): 1313- 32.

Bennett, Jane. 2010. Vibrant Matter: A Political Ecology of Things. Durham, NC: Duke University Press.

Bentham, Jeremy. 1864. Theory of Legislation. London: Trübner \& Co.

Biermann, Frank. 2014. Earth System Governance: World Politics in the Anthropocene. Cambridge, MA: MIT Press.

Bogost, Ian. 2010. Persuasive Games: The Expressive Power of Videogames. Cambridge, MA: MIT Press.

Bonneuil, Christophe, and Jean-Baptiste Fressoz. 2016. The Shock of the Anthropocene: The Earth, History and Us. Translated edition. London: Verso.

Brondízio, Eduardo S. 2016. "Foundations of Environmental Anthropology." National SocioEnvironmental Synthesis Center (SESYNC) Lecture. Accessed January 15, 2018. https://www.youtube.com/watch?v=9kOdvJeeiNc.

Eduardo S. Brondízio, and Emilio F. Moran, eds. 2013. Human-Environment Interactions: Current and Future Directions. Dordrecht: Springer.

Brondízio, Eduardo S., Karen O'Brien, Xuemei Bai, Frank Biermann, Will Steffen, Frans Berkhout, Christophe Cudennec, Maria Carmen Lemos, Alexander Wolfe, Jose Palma-Oliveira, Chen-Tung, and Arthur Chen. 2016. "Re-Conceptualizing the Anthropocene: A Call for Collaboration." Global Environmental Change 39: 318-27.

Campbell, Ben. 2005. "Changing Protection Policies and Ethnographies of Environmental Engagement." Conservation and Society 3 (2): 280- 322.

Carson, Rachel. (1962) 2002. Silent Spring. Boston: Houghton Mifflin Harcourt. 
Chakrabarty, Dipesh. 2009. "The Climate of History: Four Theses.” Critical Inquiry 35 (2): 197- 222.

Cohen, Jeffrey Jerome. 2015. Stone: An Ecology of the Inhuman. Minneapolis: University Of Minnesota Press.

Collins, Marsha Suzan. 2002. The Soledades: Góngora's Masque of the Imagination. Columbia: University of Missouri Press.

Collins, Samuel Gerald, Matthew Durington, and Harjant Gill. 2017. "Multimodality: An Invitation." American Anthropologist 119 (1): 142- 46.

Conklin, Harold C. 1955. The Relation of Hanunóo Culture to the Plant World. Rome: Food and Agricultural Organization of the United Nations.

Costanza, Robert, Sander van derLeeuw, Kathy Hibbard, Steve Aulenbach, Simon Brewer, Michael Burek, Sarah Cornell, et al. 2012. "Developing an Integrated History and Future of People on Earth (IHOPE)." Current Opinion in Environmental Sustainability 4 (1): 106- 14.

Crate, Susan A. 2011. "Climate and Culture: Anthropology in the Era of Contemporary Climate Change." Annual Review of Anthropology 40: 175- 94.

Crutzen, Paul J., and Eugene Stoermer. 2000. “The Anthropocene.” Global Change Newsletter 41 (1): $17-18$.

Dewulf, Art, Greet François, Claudia Pahl-Wostl, and Tharsi Taillieu. 2007. "A Framing Approach to Cross-Disciplinary Research Collaboration: Experiences from a Large-Scale Research Project on Adaptive Water Management.” Ecology and Society 12 (2): 14.

Dove, Michael R. 2013. The Anthropology of Climate Change: An Historical Reader. DeKalb, IL: John Wiley \& Sons.

Droogers, André F. 1996. “Methodological Ludism: Beyond Religionism and Reductionism.” In Conflicts in Social Science, edited by Anton Harskamp. 44- 67. London: Routledge.

Droogers, André F. 1999. “ The Third Bank of the River: Play, Methodological Ludism, and the Definition of Religion." In The Pragmatics of Defining Religion: Contexts, Concepts, and Contests, edited by Jan Platvoet and Arie L. Molendijk, 285-313. Leiden: Brill.

Einaudi, Ludovico. 2016. “Elegy for the Arctic.” https://www.youtube.com/watch?v=2DLnhdnSUVs.

Findlen, Paula. 1998. "Between Carnival and Lent: The Scientific Revolution at the Margins of Culture." Configurations 6 (2): 243- 67.

Foucault, Michel. 1994. The Order of Things: An Archaeology of Human Sciences. New York: Vintage Books.

Foucault, Michel. 2010. Archaeology of Knowledge and the Discourse on Language. Princeton, NJ: Vintage Books. 
Freire, Paulo. 2000. Pedagogy of the Oppressed. Edited by Donaldo Macedo. Translated by Myra Bergman Ramos. New York: Continuum.

Geertz, Clifford. 1972. "Deep Play: Notes on the Balinese Cockfight." Daedalus 101 (1): 1- 37.

Ghosh, Amitav. 2016. The Great Derangement: Climate Change and the Unthinkable. Reprint edition. Chicago: University Of Chicago Press.

Giroux, Henry A. 2011. On Critical Pedagogy. New York: Continuum.

Guattari, Felix. 2014. The Three Ecologies. London: Bloomsbury.

Hamblin, Jacob Darwin. 2013. Arming Mother Nature: The Birth of Catastrophic Environmentalism. Oxford: Oxford University Press.

Haraway, Donna J. 2007. When Species Meet. Minneapolis: University of Minnesota Press.

Haraway, Donna, Noboru Ishikawa, Scott F. Gilbert, Kenneth Olwig, Anna L. Tsing, and Nils Bubandt. 2016. "Anthropologists Are Talking—about the Anthropocene." Ethnos 81 (3): 535- 64.

hooks, bell. 1994. Teaching to Transgress: Education as the Practice of Freedom. New York: Routledge.

Horace. 1929. Horace: Satires, Epistles and Ars Poetica. Revised. Cambridge, MA: Harvard University Press.

Howe, Cymene. 2015. "Latin America in the Anthropocene: Energy Transitions and Climate Change Mitigations." Journal of Latin American and Caribbean Anthropology 20 (2): 231-41.

Howe, Cymene, and Dominic Boyer. 2015. "Aeolian Politics." Distinktion: Scandinavian Journal of Social Theory 16 (1): 31- 48.

Howe, Cymene, and Anand Pandian. 2016. "Lexicon for an Anthropocene Yet Unseen." Cultural Anthropology website, January 21. https://culanth.org/fieldsights/803-lexicon-for-an-anthropoceneyet-unseen.

Ingold, Tim. 2000. The Perception of the Environment: Essays on Livelihood, Dwelling and Skill. London: Routledge.

Jonsson, Fredrik Albritton. 2012. "The Industrial Revolution in the Anthropocene." Journal of Modern History 84 (3): 679- 96.

Jonsson, Fredrik Albritton. 2014. "The Origins of Cornucopianism: A Preliminary Genealogy." Critical Historical Studies 1 (1): 151- 68.

Kelly, Jason M. 2015. Fjord/Glacier/River. Accessed May 1, 2018. http://www.jasonmkelly.com/fjordglacierriver-allan.

Jason M. Kelly, and Fiona P. McDonald, eds. 2017. An Anthropocene Primer, Version 1.0. Accessed May 3, 2018. http://anthropoceneprimer.org. 
Jason M. Kelly, Philip Scarpino, Helen Berry, James Syvitski, and Michel Meybeck, eds. 2017. Rivers of the Anthropocene. Oakland: University of California Press. https://www.luminosoa.org/site/books/10.1525/luminos.43/.

Kennedy, George Alexander, and Glyn P. Norton. 1989. The Cambridge History of Literary Criticism: The Renaissance. Vol. 3. Cambridge: Cambridge University Press.

Kirksey, Eben. 2014. The Multispecies Salon: Gleanings from a Para-Site. Durham, NC: Duke University Press.

Kirksey, Eben, and Stefan Helmreich. 2010. "The Emergence of Multispecies Ethnography." Cultural Anthropology website, June 14. https://culanth.org/fieldsights/277-the-emergence-of-multispeciesethnography.

Knibbe, Kim, and André Droogers. 2011. "Methodological Ludism and the Academic Study of Religion." Method \& Theory in the Study of Religion (3/4): 283.

Kohn, Eduardo. 2013. How Forests Think: Toward an Anthropology beyond the Human. Berkeley: University of California Press.

Kristiansen, Per, and Robert Rasmussen. 2014. Building a Better Business Using the Lego Serious Play Method. Hoboken, NJ: Wiley.

Landow, George P. 1997. Hypertext 2.0: The Convergence of Contemporary Critical Theory and Technology. Second edition. Baltimore, MD: Johns Hopkins University Press.

Latour, Bruno. 1988. Science in Action: How to Follow Scientists and Engineers through Society. Boston: Harvard University Press.

Latour, Bruno. 2004. Politics of Nature: How to Bring the Sciences into Democracy. Translated by Catherine Porter. Cambridge: Harvard University Press.

Latour, Bruno. 2005. Reassembling the Social: An Introduction to Actor-Network-Theory. Oxford: Oxford University Press.

Latour, Bruno. 2014. "Anthropology at the Time of the Anthropocene-a Personal View of What Is to Be Studied.” Distinguished lecture at the American Anthropological Association meeting, Washington, DC.

Latour, Bruno. 2017. Facing Gaia: Eight Lectures on the New Climatic Regime. Cambridge: Polity.

Latour, Bruno, and Philippe Descola. 2013. " Approaches to the Anthropocene: A Conversation with Philippe Descola and Bruno Latour." Discussion at the University of British Columbia Museum of Anthropology, September 25. https://www.youtube.com/watch?v=MDeGaYkhVSo.

Latour, Bruno, and Steve Woolgar. 1986. Laboratory Life: The Construction of Scientific Facts. Edited by Jonas Salk. Princeton, NJ: Princeton University Press.

Lewis, Simon L., and Mark A. Maslin. 2015. “Defining the Anthropocene.” Nature 519 (7542): 171- 80. 
Ligorano Reese. 2014. “Dawn of the Anthropocene.” https://www.youtube.com/watch?v=GooCpQZHG0.

Lorimer, Jamie. 2012. "Multinatural Geographies for the Anthropocene." Progress in Human Geography 36 (5): 593-612.

Lövbrand, Eva, Silke Beck, Jason Chilvers, Tim Forsyth, Johan Hedrén, Mike Hulme, Rolf Lidskog, and Eleftheria Vasileiadou. 2015. "Who Speaks for the Future of Earth? How Critical Social Science Can Extend the Conversation on the Anthropocene." Global Environmental Change 32 (May): 211- 18.

Malm, Andreas. 2016. Fossil Capital: The Rise of Steam Power and the Roots of Global Warming. London: Verso.

Malm, Andreas, and Alf Hornborg. 2014. "The Geology of Mankind? A Critique of the Anthropocene Narrative." Anthropocene Review 1 (1): 62- 69.

Martinez-Alier, Juan. 2003. The Environmentalism of the Poor: A Study of Ecological Conflicts and Valuation. Cheltenham, UK: Edward Elgar Publisher.

McDonald, Fiona P., and Jason M. Kelly. Forthcoming. "How to Do Open Peer Review in the Anthropocene." Anthropology News.

Meadows, Donella, Dennis Meadows, Jørgen Randers, and William Behrens III. 1972. Limits to Growth. New York: Club of Rome.

Mollinga, Peter P. 2010. "Boundary Work and the Complexity of Natural Resources Management." Crop Science 50 (S1): S1-9.

Moore, Amelia. 2015a. “The Anthropocene: A Critical Exploration.” Environment and Society 6 (1): 13.

Moore, Amelia. 2015b. "Islands of Difference: Design, Urbanism, and Sustainable Tourism in the Anthropocene Caribbean.” Journal of Latin American and Caribbean Anthropology 20 (3): 513- 32.

Moore, Amelia. 2018. Destination Anthropocene: Global Change Science, Tourism, and the Rebranding of Island Space in the Bahamas. Oakland: University of California Press.

Moore, Jason W. 2015. Capitalism in the Web of Life: Ecology and the Accumulation of Capital. New York: Verso.

Jason W. Moore, ed. 2016. Anthropocene or Capitalocene?: Nature, History, and the Crisis of Capitalism. Oakland: PM Press.

Morton, Timothy. 2017. Humankind: Solidarity with Non-Human People. Brooklyn, NY: Verso.

Netting, Robert McC. 1968. Hill Farmers of Nigeria: Cultural Ecology of the Kofyar of the Jos Plateau. Seattle: University of Washington Press. 
Nixon, Rob. 2013. Slow Violence and the Environmentalism of the Poor. Cambridge, MA: Harvard University Press.

Purdy, Jedediah. 2015. After Nature: A Politics for the Anthropocene. Cambridge, MA: Harvard University Press.

Rousell, David. 2015. "Dwelling in the Anthropocene: Reimagining University Learning Environments in Response to Social and Ecological Change." Australian Journal of Environmental Education 32 (2): $137-53$.

Ruddiman, William F. 2003. "The Anthropogenic Greenhouse Era Began Thousands of Years Ago." Climatic Change 61 (3): 261-93.

Schmidt, Jeremy J., Peter G. Brown, and Christopher J. Orr. 2016. "Ethics in the Anthropocene: A Research Agenda." The Anthropocene Review 3 (3): 188- 200.

Shapin, Steven. 2010. Never Pure: Historical Studies of Science as If It Was Produced by People with Bodies, Situated in Time, Space, Culture, and Society, and Struggling for Credibility and Authority. Baltimore, MD: Johns Hopkins University Press.

Shapin, Steven, and Simon Schaffer. 1989. Leviathan and the Air-Pump: Hobbes, Boyle, and the Experimental Life. Princeton, NJ: Princeton University Press.

Statler, Matt, Loizos Heracleous, and Claus D. Jacobs. 2011. "Serious Play as a Practice of Paradox." Journal of Applied Behavioral Science 47 (2): 236- 56.

Statler, Matt, Johan Roos, and Bart Victor. 2009. “Ain't Misbehavin’: Taking Play Seriously in Organizations.” Journal of Change Management 9 (1): 87- 107.

Steffen, Will, Jacques Grinevald, Paul Crutzen, and John McNeill. 2011. "The Anthropocene: Conceptual and Historical Perspectives." Philosophical Transactions of the Royal Society A: Mathematical, Physical and Engineering Sciences 369 (1938): 842- 67.

Steward, Julian Haynes. 1955. Theory of Culture Change: The Methodology of Multilinear Evolution. Urbana: University of Illinois Press.

Stoller, Paul. 2018. "Logging on to the Anthropocene." Huffington Post website. Accessed May 5, 2018. https://www.huffingtonpost.com/entry/logging-on-to-theanthropocene us 5a5ce5a1e4b0a233482e0da0.

Stone, Christopher D. 2010. Should Trees Have Standing?: Law, Morality, and the Environment. Oxford: Oxford University Press.

Toivanen, T., K. Lummaa, A. Majava, P. Järvensivu, V. Lähde, T. Vaden, and J. T. Eronen. 2017. “The Many Anthropocenes: A Transdisciplinary Challenge for the Anthropocene Research." The Anthropocene Review 4 (3): 183-98.

Tsing, Anna Lowenhaupt. 2015. The Mushroom at the End of the World: On the Possibility of Life in Capitalist Ruins. Princeton, NJ: Princeton University Press. 
Turner, Victor. 1990. “ Are There Universals of Performance in Myth, Ritual, and Drama?” In By Means of Performance: Intercultural Studies of Theatre and Ritual, edited by Richard Schechner and Willa Appel, 8- 18. Cambridge: Cambridge University Press.

VPRO Documentary. 2017. "The Anthropocene: The Age of Mankind." https://www.youtube.com/watch?v=AW138ZTKioM.

J. R. Wagner, ed. 2013. The Social Life of Water. Oxford: Berghahn Books.

Walker, Gordon. 2009. "Globalizing Environmental Justice: The Geography and Politics of Frame Contextualization and Evolution." Global Social Policy 9 (3): 355- 82.

Williams, Raymond. 1985. Keywords: A Vocabulary of Culture and Society. Revised. New York: Oxford University Press.

Wind, Edgar. 1968. Pagan Mysteries in the Renaissance. Revised. New York: W. W. Norton \& Co.

Zalasiewicz, Jan. 2015. “Epochs: Disputed Start Dates for Anthropocene.” Nature 520 (7548): 436- 36.

Zalasiewicz, Jan, Colin N. Waters, Mark Williams, Anthony D. Barnosky, Alejandro Cearreta, Paul Crutzen, Erle Ellis, et al. 2015. "When Did the Anthropocene Begin? A Mid-Twentieth Century Boundary Level Is Stratigraphically Optimal.” Quaternary International 383 (October): 196- 203.

Zalasiewicz, Jan, Mark Williams, Richard Fortey, Alan Smith, Tiffany L. Barry, Angela L. Coe, Paul R. Bown, et al. 2011. "Stratigraphy of the Anthropocene." Philosophical Transactions of the Royal Society A: Mathematical, Physical and Engineering Sciences 369 (1938): 1036- 55.

Zalasiewicz, Jan, Mark Williams, Alan Haywood, and Michael Ellis. 2011. "The Anthropocene: A New Epoch of Geological Time?" Philosophical Transactions of the Royal Society A: Mathematical, Physical and Engineering Sciences 369 (1938): 835- 41.

Zalasiewicz, Jan, Mark Williams, Alan Smith, Tiffany L. Barry, Angela L. Coe, Paul R. Bown, Patrick Brenchley, et al. 2008. “Are We Now Living in the Anthropocene?" GSA Today 18 (2): 4.

Zylinska, Joanna. 2014. Minimal Ethics for the Anthropocene. London: Open Humanities Press. http://www.openhumanitiespress.org/books/titles/minimal-ethics-for-the-anthropocene/. 